\title{
Gastric T-Cell Non-Hodgkin Lymphoma
}

National Cancer Institute

\section{Source}

National Cancer Institute. Gastric T-Cell Non-Hodgkin Lymphoma. NCI Thesaurus. Code C5254.

A rare, extranodal T-cell non-Hodgkin lymphoma that arises from the stomach with the bulk of the mass located in the stomach. 